\title{
Trakya Bölgesinde Tarımsal Mekanizasyon Düzeyinin İllere Göre Belirlenmesi
}

\section{Derya İlkay ABDİKOĞLU $1 \%$}

Namık Kemal Üniversitesi, Ziraat Fakültesi, Tarım Ekonomisi Bölümü, Tekirdağ, Türkiye https://orcid.org/0000-0003-0273-3323

$\square$ : deryailkay@nku.edu.tr

\section{ÖZET}

Bu çalışmada Türkiye ve Trakya bölgesi ile Edirne, Kırklareli ve Tekirdağ illerinin tarımsal mekanizasyon düzeyi göstergeleri hesaplanarak, 2008 - 2017 yılları arasındaki mekanizasyon düzeyindeki değişim incelenmiş, iller arasında ve Türkiye ile karşılaştırmalar yapılmıştır. Ayrıca trend analizi ile 2018 - 2023 yılları için işlenen alana düşen traktör gücü tahmin edilmiştir. Son 10 yılda 1000 ha alana düşen traktör sayısında Türkiye'de \%27.9, Trakya bölgesinde \%3.7, Edirne'de \%13.9 ve Kırklareli'nde \%6.1 oranında artış olurken, Tekirdağ da \%5.8 oranında azalma mevcuttur. Bunun nedeni yıllar içerisinde Tekirdağ ilinde traktör sayısındaki artış oranının, işlenen alandaki artış oranı kadar yüksek olmamasıdır. Türkiye'de işlenen alana düşen traktör gücü sürekli artış eğilimde olup 2008 yllında $1.63 \mathrm{~kW} / \mathrm{ha}$ iken 2017 yllında $2.12 \mathrm{~kW} / \mathrm{ha}$ 'dır. Trakya bölgesinde bu rakam 2008 yılında $2.62 \mathrm{~kW} / \mathrm{ha}$ iken 2017 yılında $2.80 \mathrm{~kW} /$ ha'a yükselmiştir. 2008 yılında traktör başına alet/makine sayısı Türkiye'de 7.68, Trakya bölgesinde 9.18 iken, 2017 yılında Türkiye'de 7.26, Trakya bölgesinde 9.24'tür. Edirne ve Kırklareli illerinde yıllar içinde alet/makine sayısı, traktör sayısına göre daha fazla arttığından traktör başına alet/makine sayısı artmaktadır. Trend analizi sonuçlarına göre işlenen alana düşen traktör gücünün Trakya bölgesinde 2023 yılında $3.01 \mathrm{~kW} / \mathrm{ha}$ olması tahmin edilmiştir.

\section{Determining of Agricultural Mechanization Level in Thrace Region by Provinces Abstract}

\section{ABSTRACT}

In this study, agricultural mechanization indicators of Turkey, Thrace Region, Edirne, Kırklareli and Tekirdağ provinces has calculated for 2008 - 2017. The changes in the mechanization level has examined and comparisons was made. By using trend analysis, the tractor power per agricultural area for 2018-2023 was estimated. In the last 10 years, number of tractors per 1000 ha has increased $27.9 \%$ in Turkey, $3.7 \%$ in Thrace region, $13.9 \%$ in Edirne and $6.1 \%$ in Kırklareli but it has decreased $5.8 \%$ in Tekirdağ province. This is due to the fact that the rate of increase in the number of tractors in the Tekirdag province was not as high as the rate of increase in the agricultural area. Tractor power per agricultural area in Turkey is constantly increasing. While it was $1.63 \mathrm{~kW} / \mathrm{ha}$ in 2008 , it was $2.12 \mathrm{~kW} / \mathrm{ha}$ in 2017 . In Thrace region while it was $2.62 \mathrm{~kW} / \mathrm{ha}$ in 2008 , it has increased to $2.80 \mathrm{~kW} / \mathrm{ha}$ in 2017. While tools/machines per tractor was 7.68 and 9.18 in Turkey and in Thrace region, respectively, for 2008, it was 7.26 and 9.24 in Turkey and Thrace region, respectively for 2017. There is an increase in tools/machines per tractor in Edirne and Kırklareli provinces because of the number of tools/machines increased more than those of tractors. According to the trend analysis results, it is estimated that the tractor power in the area will be $3.01 \mathrm{~kW} / \mathrm{ha}$ in 2023 in the Thrace region.

Mechanization level

\section{Araştırma Makalesi}

Makale Tarihçesi

Geliş Tarihi : :03.04.2019

Kabul Tarihi : 17.05 .2019

Anahtar Kelimeler
Mekanizasyon düzeyi
Mekanizasyon göstergeleri
Tekirdağ
Edirne
Kırklareli

\section{Research Article}

$\begin{array}{ll}\text { Article History } & \\ \text { Received } & : 03.04 .2019 \\ \text { Accepted } & : 17.05 .2019\end{array}$

\section{Keywords}

Mechanization indicators

Tekirdağ

Edirne

Kırklareli

To Cite : Abdikoğlu Dİ, 2019. Trakya Bölgesinde Tarımsal Mekanizasyon Düzeyinin İllere Göre Belirlenmesi. KSÜ Tarım ve Doğa Derg 22(6): 865-871. DOI: 10.18016/ksutarimdoga.vi.548701. 


\section{GİRIŞ}

Tarımsal mekanizasyon, tarımda ileri teknolojilerin uygulanmasını, ayrıca toprak, su, gübre, ilaç, vb. girdilerin etkin kullanımını olanaklı kılarak, verimliliği sağlayan önemli bir üretim aracıdır (Korucu ve ark., 2015). Tarımsal mekanizasyon düzeyi bölgelerin teknik ve ekonomik yapısına bağlı olarak değişim gösterebilmektedir. Tarımsal mekanizasyon göstergeleri kullanılarak tarımsal mekanizasyon düzeyinin belirlenmesi; illerin, bölgelerin ve ülkelerin tarımsal mekanizasyon düzeylerinin karşılaştırılması ve değerlendirilmesi açısından önemlidir.

Tarımsal üretimde kullanılan temel güç kaynağı traktördür. Bu nedenle tarım traktörleri, bölgelerin tarımsal mekanizasyon düzeylerinin belirlenmesinde dikkate alınan en önemli göstergedir. En yaygın kullanılan traktör esaslı mekanizasyon düzeyi göstergeleri işlenen alana düşen traktör gücü (kW/ha), 1000 ha işlenen alana düşen traktör sayısı (traktör sayısı/1000 ha), traktör başına işlenen alan (ha/traktör sayısı) ve traktör başına alet/makine sayısı (aletmakine sayısı/traktör)'dır (Sabancı ve ark., 2003).

Türkiye'de bölgelerin ve illerin mekanizasyon düzeyinin belirlenmesine yönelik birçok çalışma mevcuttur. Bölge bazında yapılan çalışmalarda Özpinar (2001) Marmara bölgesinin, Özgüven ve ark. (2010) ile Korucu ve ark. (2015) Türkiye'nin tarımsal bölgelerinin, Baran ve ark. (2014) Batı Marmara bölgesinin, Özmen (2014) TRA1 Düzey 2 bölgesinin, Altuntaş (2016) Türkiye'nin coğrafi bölgelerinin, Bozkurt (2016) Harran Ovasının, Akar ve Çelik (2017) Muş Ovasının tarımsal mekanizasyon düzeyini belirlemişlerdir. Durgut ve Arın (2005), Trakya yöresinde bağcılık yapan işletmelerin mekanizasyon düzeylerini belirlemişlerdir. İl bazında yapılan çalışmalarda ise Kök (1993) Tunceli, Işık ve ark. (2003) Bursa, Koçak (2006) Bitlis, Arıöz (2007) Ağrı, Altıkat ve Çelik (2009) Erzurum, Altıkat ve Çelik (2011) Iğdır, Akar ve ark. (2012) Hatay, Gökdoğan (2012) Isparta, Lüle ve ark. (2012) Adıyaman, Gökdoğan (2014) Hakkari, Bilim ve ark. (2014) Gaziantep, Altıntaş (2015) Eskişehir, Korucu ve ark. (2015) Kahramanmaraş, Doruk (2016) Denizli, Kayhan ve ark. (2017) Kırklareli, Oğuz ve ark. (2017) Konya, Aslantürk ve Altuntaş (2018) Malatya illerinin tarımsal mekanizasyon düzeylerini incelemişlerdir. Koçtürk ve Onurbaş Avcioğlu (2007) tüm illerin mekanizasyon düzeylerini belirlemişlerdir. Conley ve Lambert (1981) traktör beygir gücü üzerinde etkili olan faktörleri, Unakıtan ve Akdemir (2007, 2015) Türkiye'de, Biondi ve ark. (2012) ise İtalya, Fransa ve Amerika Birleşik Devletleri'nde, traktör talebi üzerinde etkili olan faktörleri belirlemişler ve traktör talebini kısa dönem için tahmin etmişlerdir.

Bu çalışmanın amacı, Edirne, Kırklareli ve Tekirdağ illeri ile Türkiye için traktör sayılarını ve tarım alanlarını baz alarak son 10 yıla ait tarımsal mekanizasyon göstergelerini hesaplayarak mekanizasyon düzeyini belirlemek, elde edilen sonuçları il bazında birbirleriyle ve Türkiye ile karşılaştırmak ve yıllar içerisinde mekanizasyon düzeyinde meydana gelen değişimi belirlemektir. Ayrıca trend analizi ile 2018 - 2023 yılları için işlenen alana düşen traktör gücünün tahmin edilmesi amaçlanmıştır.

\section{MATERYAL ve YÖNTEM}

Çalışmanın verileri Türkiye İstatistik Kurumu'ndan (TÜİK) alınmıştır. Çalışmada Edirne, Kırklareli, Tekirdağ ve Türkiye'ye ait 2008 - 2017 yılları arasındaki tarım alanları ve traktör sayılarına ilişkin veriler kullanılmıştır. Bu veriler değerlendirilerek Edirne, Kırklareli ve Tekirdağ illeri hem birbirleriyle hem de Türkiye ve Trakya bölgesi değerleriyle karşılaştırılmıştır. Mekanizasyon düzeyinin belirlenmesinde 1000 ha alana düşen traktör sayısı (traktör/1000 ha), bir traktöre düşen toplam alan (ha/traktör) ve birim alana düşen traktör gücü ( $\mathrm{kW} / \mathrm{ha})$ göstergeleri esas alınmıştır. $\mathrm{Bu}$ göstergelerin hesaplanmasında toplam tarım alanları, traktör sayısı ve ortalama traktör gücü değerlerinden (Lüle ve ark., 2012) yararlanılmıştır. Elde edilen veriler beygir gücü cinsinden olup, 0.7457 ile çarpllarak kW'a dönüştürülmüştür.

Traktör gücünün tahmin edilmesinde trend analizi kullanılmıştır. Trend (eğilim) analizi bir zaman serisinin uzun dönemdeki ana eğilimi olarak tanımlanan eğilimin bir doğru veya bir eğri ile ifade edilmesidir (Yavuz, 2016). Trend analizinde ele alınan zaman serisini en iyi temsil edecek trend denklemi belirlendikten sonra, gelecek dönem için tahminler elde edilir. Trendin tahmini, en küçük kareler yöntemi, hareketli ortalama ve yarıyı ortalamalar yöntemi ile yapılabilir. Bu çalışmada trend eğrisinin denklemini bulmak için en küçük kareler yöntemi kullanılmıştır. Ancak trend eğrisinin denklemini bulmak için en küçük kareler yönteminin farklı denklem türlerinin (doğrusal, logaritmik, üssel, vd.) incelenmesi gerekmektedir (Witt ve Witt, 1992). Bu çalışmada farklı denklem türleri incelenmiş ve determinasyon katsayısı $\left(r^{2}\right)$ en yüksek olan logaritmik trend denklemi uygulanarak analiz yapılmıştır.

Son 10 yıldaki traktör sayıları Çizelge 1'de gösterilmiştir. Türkiye'de 2017 yılı traktör sayısı 2008 yılı traktör sayısına göre \%22.05 artarak 1306611 adet olmuştur. Trakya bölgesinde 2008 yılı traktör sayısı 57665 iken 2017 yılı traktör sayısı 59484'tür. Trakya bölgesinde son 10 yıldaki artış oranı \%3.15’tir. 2008 2017 yılları arasında Edirne, Kırklareli ve Tekirdağ'da traktör sayılarındaki artış oranları ise sırasıyla \%2.18, $\% 6.43$ ve $\% 1.98$ 'dir. 
2008 - 2017 yılları arasında tarım alanları Çizelge 2'de gösterilmiştir. Türkiye'de toplam tarım alanları miktarı son 10 yılda \%4.57 azalarak yaklaşık 23.39 milyon ha olmuştur. Trakya bölgesinde 2008 yllında yaklaşık 951 bin ha olan tarım alanları, 2017 yılında
$\% 0.53$ azalarak yaklaşık 946 bin ha olmuştur. Son 10 yılda Edirne'de tarım alanlarında \%10.36'llk bir azalma olurken, Kırklareli'nde \%0.29'luk ve Tekirdağ' da \%8.35'lik artış meydana gelmiştir.

Çizelge 1. 2008 - 2017 yılları traktör sayıları.

\begin{tabular}{llclcc} 
Ylllar & Türkiye & Trakya Bölgesi & Edirne & Kırklareli & Tekirdağ \\
\hline 2008 & 1070528 & 57665 & 23448 & 14165 & 20052 \\
2009 & 1073334 & 57789 & 23404 & 14235 & 20150 \\
2010 & 1096484 & 58463 & 23717 & 14602 & 20144 \\
2011 & 1124795 & 58884 & 23792 & 14704 & 20388 \\
2012 & 1178049 & 59588 & 23870 & 14857 & 20861 \\
2013 & 1213374 & 59382 & 23861 & 15040 & 20481 \\
2014 & 1243100 & 58535 & 23686 & 15038 & 19811 \\
2015 & 1260152 & 58575 & 23719 & 15053 & 19803 \\
2016 & 1273399 & 59227 & 23865 & 14943 & 20419 \\
2017 & 1306611 & 59484 & 23958 & 15076 & 20450 \\
\hline
\end{tabular}

Kaynak: TÜİK, 2018

Cizelge 2. 2008 - 2017 yılları tarım alanları (ha).

\begin{tabular}{ccclll}
\multicolumn{1}{c}{ Ylllar } & Türkiye & Trakya Bölgesi & Edirne & Kırklareli & Tekirdă̆ \\
\hline 2008 & 24505223 & 951146.6 & 350381 & 234653.1 & 366112.5 \\
2009 & 24294681 & 929644.8 & 343227.4 & 230546.2 & 355871.2 \\
2010 & 24394205 & 954451.9 & 361653.2 & 232358.3 & 360440.4 \\
2011 & 23613761 & 910647.7 & 328176.6 & 225059.6 & 357411.4 \\
2012 & 23781999 & 816683.3 & 302334.5 & 191418.9 & 322929.9 \\
2013 & 23805512 & 823635.1 & 291154.2 & 211665.7 & 320815.2 \\
2014 & 23940714 & 890761.9 & 313808 & 227290.7 & 349663.2 \\
2015 & 23933614 & 922524.7 & 314449.4 & 225800.2 & 382275 \\
2016 & 23762572 & 957588.7 & 320120.3 & 236930.2 & 400538.2 \\
2017 & 23385093 & 946095.6 & 314098 & 235326.1 & 396671.5 \\
\hline
\end{tabular}

Kaynak: TÜİK, 2018

\section{ARAŞTIRMA BULGULARI ve TARTIŞMA}

Türkiye ve Trakya bölgesi ile Edirne, Kırklareli ve Tekirdağ illerinin tarımsal mekanizasyon düzeyi göstergeleri hesaplanmıştır. Çizelge 3'te 1000 ha işlenen alana düşen traktör sayısı (traktör sayısı/1000 ha) değerleri gösterilmiştir. 2008 - 2017 yılları arasında Türkiye'de işlenen alana düşen traktör sayısı sürekli artmaktadır. Bunun sebebi tarım alanları azalırken, traktör sayısının artmasıdır. 1000 ha işlenen alana düşen traktör sayısı Trakya bölgesinde 2008 yılında 60.63 traktör/1000ha iken, 2017 yllında 62.87 traktör /1000 ha olmuştur. Tekirdağ ilinde ise traktör sayısı yıllar içinde çok değişmezken, tarım alanları artmaktadır. $\mathrm{Bu}$ nedenle Tekirdağ ilinde işlenen alana düşen traktör sayısı azalmaktadır. Altuntaş (2016), çalışmasında 2013 yılı verilerini kullanarak 1000 ha işlenen alana düşen traktör sayısını Marmara bölgesi için 127.49 traktör /1000 ha olarak hesaplamıştır. Baran ve ark. (2014), Balıkesir, Çanakkale, Edirne, Kırklareli ve Tekirdağ illerini kapsayan Batı Marmara bölgesinde 1000 ha işlenen alana düşen traktör sayısını 80.46 traktör /1000 ha olarak hesaplamışlardır. Koçtürk ve Onurbaş Avcıoğlu (2007), çalışmalarında 1000 ha işlenen alana düşen traktör sayısını Edirne, Kırklareli, Tekirdağ illeri ve Marmara bölgesi için sirasıyla 65.8 traktör /1000 ha, 57.8 traktör /1000 ha, 55.3 traktör /1000 ha ve 94.3 traktör /1000 ha olarak hesaplamışlardır.

Traktör başına işlenen alan (ha/traktör sayısı) Çizelge 4'te gösterilmiştir. 2008- 2017 yılları arası Türkiye'de traktör başına işlenen alan miktarında sürekli bir azalış mevcuttur. Traktör başına işlenen alan miktarı Trakya bölgesi, Edirne ve Kırklareli’nde genel eğilim azalış yönündeyken, Tekirdağ'da ise artış yönündedir. Traktör başına işlenen alan Marmara bölgesinde 7.84 ha/traktör (Altuntaş, 2016), Batı Marmara bölgesinde 12.43 ha/traktör (Baran ve ark., 2014), Edirne, Kırklareli ve Tekirdağ illerinde sirasıyla 15.2 ha/traktör, 17.3 ha/traktör ve 18.1 ha/traktör (Koçtürk ve Onurbaş Avcıŏlu, 2007) olarak hesaplanmıştır.

İşlenen alana düşen traktör gücü $(\mathrm{kW} / \mathrm{ha})$ değerleri Çizelge 5'te gösterilmiştir. Son 10 yılda Türkiye'de işlenen alana düşen traktör gücü sürekli bir artış göstermektedir. İşlenen alana düşen traktör gücü Trakya bölgesinde 2012 yllına kadar artarken, 2012 yılından sonra azalmıştır. Bunun nedeni Trakya bölgesinde son 10 yılda traktör gücü sürekli artış gösterirken, tarım alanlarının 2012 yılına kadar 
azalması ve 2012 yılından sonra yeniden artmasıdır. İşlenen alana düşen traktör gücü Marmara bölgesinde $5.48 \mathrm{~kW} / \mathrm{ha}$ (Altuntaş, 2016), Batı Marmara bölgesinde $3.07 \mathrm{~kW} / \mathrm{ha}$ (Baran ve ark., 2014), Edirne, Kırklareli ve Tekirdağ illerinde sirasiyla $2.67 \mathrm{~kW} / \mathrm{ha}, 2.34 \mathrm{~kW} /$ ha ve $2.24 \mathrm{~kW} / \mathrm{ha}$ (Koçtürk ve Onurbaş Avcıŏ̆lu, 2007) olarak hesaplanmıştır.
2017 yılında işlenen alana düşen traktör gücü değerleri 2008 yılı değerleri ile karşılaştırıldığında Edirne ve Kırklareli'nde artış, Tekirdağ'da ise azalış görülmüştür. Bu durum Tekirdağ ilindeki traktör gücündeki artışın, işlenen alan miktarındaki artış kadar yüksek olmamasından kaynaklanmaktadır.

Çizelge 3. 1000 ha işlenen alana düşen traktör sayısı (traktör sayısı/1000 ha).

\begin{tabular}{lccccc}
\hline Yillar & Türkiye & Trakya Bölgesi & Edirne & Kirklareli & Tekirdağ \\
\hline 2008 & 43.69 & 60.63 & 66.92 & 60.37 & 54.77 \\
2009 & 44.18 & 62.16 & 68.19 & 61.74 & 56.62 \\
2010 & 44.95 & 61.25 & 65.58 & 62.84 & 55.89 \\
2011 & 47.63 & 64.66 & 72.50 & 65.33 & 57.04 \\
2012 & 49.54 & 72.96 & 78.95 & 77.62 & 64.60 \\
2013 & 50.97 & 72.10 & 81.95 & 71.06 & 63.84 \\
2014 & 51.92 & 65.71 & 75.48 & 66.16 & 56.66 \\
2015 & 52.65 & 63.49 & 75.43 & 66.67 & 51.80 \\
2016 & 53.59 & 61.85 & 74.55 & 63.07 & 50.98 \\
2017 & 55.87 & 62.87 & 76.28 & 64.06 & 51.55 \\
\hline
\end{tabular}

Çizelge 4. Traktör başına işlenen alan (ha/traktör sayısı).

\begin{tabular}{lccccc} 
Yıllar & Türkiye & Trakya Bölgesi & Edirne & Kırklareli & Tekirdağ \\
\hline 2008 & 22.89 & 16.49 & 14.94 & 16.57 & 18.26 \\
2009 & 22.63 & 16.09 & 14.67 & 16.20 & 17.66 \\
2010 & 22.25 & 16.33 & 15.25 & 15.91 & 17.89 \\
2011 & 20.99 & 15.47 & 13.79 & 15.31 & 17.53 \\
2012 & 20.19 & 13.71 & 12.67 & 12.88 & 15.48 \\
2013 & 19.62 & 13.87 & 12.20 & 14.07 & 15.66 \\
2014 & 19.26 & 15.22 & 13.25 & 15.11 & 17.65 \\
2015 & 18.99 & 15.75 & 13.41 & 15.00 & 19.30 \\
2016 & 18.66 & 16.17 & 13.11 & 15.86 & 19.62 \\
2017 & 17.90 & 15.91 & & 15.61 & 19.40 \\
\hline
\end{tabular}

Çizelge 5. İşlenen alana düşen traktör gücü (kW/ha).

\begin{tabular}{lccccc} 
Yıllar & Türkiye & Trakya Bölgesi & Edirne & Kırklareli & Tekirdağ \\
\hline 2008 & 1.63 & 2.62 & 2.73 & 2.37 & 2.67 \\
2009 & 1.65 & 2.69 & 2.79 & 2.49 & 2.76 \\
2010 & 1.69 & 2.67 & 2.69 & 2.62 & 2.78 \\
2011 & 1.78 & 2.83 & 2.98 & 3.12 & 2.84 \\
2012 & 1.86 & 3.17 & 3.26 & 2.86 & 3.12 \\
2013 & 1.92 & 3.16 & 3.39 & 2.67 & 3.14 \\
2014 & 1.95 & 2.88 & 3.13 & 2.89 & 2.79 \\
2015 & 1.98 & 2.83 & 3.13 & 2.74 & 2.55 \\
2016 & 2.02 & 2.74 & 3.10 & 2.81 & 2.45 \\
2017 & 2.12 & 2.80 & 3.19 & & 2.49 \\
\hline
\end{tabular}

2008 - 2017 yılları arasında Türkiye'de traktör başına alet/makine sayısının azaldığı, Trakya bölgesinde ise fazla değişim olmadığı görülmektedir (Çizelge 6). Traktör başına düşen alet/makine sayısında Edirne ve Kırklareli illerinde artış görülürken, Tekirdağ'da azalma görülmektedir. $\mathrm{Bu}$ durum yıllar içinde Tekirdağ ilinde traktör sayısında önemli bir değişim olmazken, tarım alet ve makineleri sayısının azalması ile açıklanabilir. Koçtürk ve Onurbaş Avcıoğlu (2007), çalışmalarında traktör başına alet/makine sayısı Edirne, Kırklareli ve Tekirdağ illeri için sırasıyla 5 ekipman/traktör, $\quad 6.4 \quad$ ekipman/traktör, 8 ekipman/traktör olarak hesaplamışlardır.

Trakya bölgesindeki 2008-2017 yılları arasındaki işlenen alana düşen traktör gücü $(\mathrm{kW} / \mathrm{ha})$ değişimden yola çıkılarak trend analizi yardımıyla 2018-2023 yılları için işlenen alana düşen traktör gücü tahmin edilmiştir. Yapılan trend analizine göre işlenen alana 
düşen traktör gücünün 2018 yılında $2.94 \mathrm{~kW} / \mathrm{ha}, 2023$ yılında $3.01 \mathrm{~kW} / \mathrm{ha}$ olması beklenmektedir.

Arazi toplulaştırmasıyla birlikte işletme başına düşen arazi büyüklüğü artmaktadır. Bunun sonucunda işletmeler yüksek güçte bir traktörle daha az işgücü kullanarak, daha hızlı ve daha verimli olarak çalışabilmektedir. Ekonomik ömrünü dolduran traktörlerin yerine daha yüksek güce sahip traktörlerin satın alınması da işlenen alan başına traktör gücünü arttıran bir nedendir.

Çizelge 6. Traktör başına alet/makine sayısı (alet-makine sayısı/traktör).

\begin{tabular}{lccccc} 
& Türkiye & Trakya Bölgesi & Edirne & Kırklareli & Tekirdağ \\
\hline 2008 & 7.68 & 9.18 & 8.92 & 8.31 & 10.09 \\
2009 & 7.69 & 9.18 & 8.89 & 8.34 & 10.13 \\
2010 & 7.71 & 9.22 & 8.81 & 8.28 & 10.37 \\
2011 & 7.64 & 9.24 & 8.90 & 8.29 & 10.32 \\
2012 & 7.45 & 9.39 & 8.94 & 8.54 & 10.49 \\
2013 & 7.33 & 9.28 & 8.98 & 8.58 & 10.15 \\
2014 & 7.26 & 9.14 & 9.06 & 8.61 & 9.63 \\
2015 & 7.26 & 9.30 & 9.12 & 8.81 & 9.88 \\
2016 & 7.29 & 9.23 & 9.09 & 8.85 & 9.66 \\
2017 & 7.26 & 9.24 & 9.13 & 8.81 & 9.67 \\
\hline
\end{tabular}

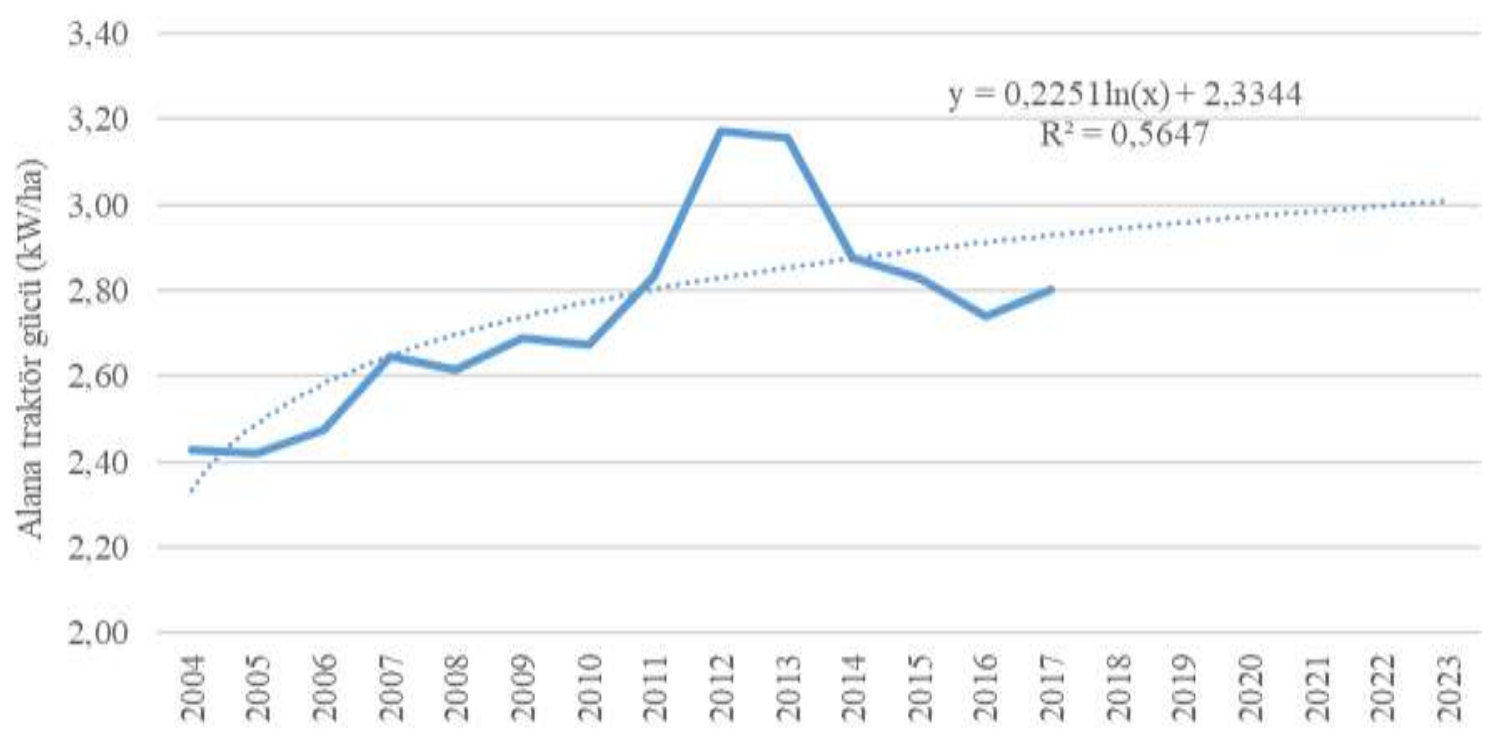

Şekil 1. Trakya bölgesinde işlenen alana düşen traktör gücü trend analizi.

\section{SONUÇ ve ÖNERILER}

$\mathrm{Bu}$ çalışmada, Trakya bölgesinin tarımsal mekanizasyon düzeyinin Tekirdağ, Edirne ve Kırklareli illeri bazında 2008-2017 yılları arasındaki değişimleri belirlenmeye çalışılmıştır.

Trakya bölgesindeki tarım alanları ve traktör sayıları incelendiğinde, işlenen tarım alanı yönünden ilk sırayı Tekirdağ alırken, en fazla traktöre sahip olan il Edirne'dir. Kırklareli hem işlenen alan hem de traktör sayısı açısından sonuncu sıradadır. Traktör başına düşen alet/makine sayısında ise Tekirdağ ilk sırada yer almaktadir.

Son 10 yılda 1000 ha alana düşen traktör sayısında Türkiye ve Trakya bölgesi ile Edirne ve Kırklareli illerinde artış gözlenmiştir. Tekirdağ ilinde ise azalma mevcuttur. Bunun nedeni yıllar içerisinde Tekirdağ ilinde traktör sayısındaki artış oranının, işlenen alandaki artış oranı kadar yüksek olmamasıdır.
Traktör başına işlenen alan incelendiğinde son 10 yılda Türkiye'de sürekli bir azalış görülmektedir. Traktör başına işlenen alan miktarı Trakya bölgesi, Edirne ve Kırklareli'nde genel eğilim azalış yönündeyken, Tekirdağ'da ise artış yönündedir.

Son 10 yılda Türkiye'de işlenen alana düşen traktör gücü sürekli artmaktadır. Yıllar içerisinde dalgalanma olmakla birlikte Trakya bölgesi ile Edirne ve Kırklareli illerinde artış, Tekirdağ ilinde ise azalma görülmektedir.

2008 - 2017 yılları arasında Türkiye'de traktör başına alet/makine sayısı azalmakta, Trakya bölgesinde ise fazla değişim olmamaktadır. Edirne ve Kırklareli illerinde yıllar içinde alet/makine sayısı, traktör sayısına göre daha fazla arttığından traktör başına alet/makine sayısı artmaktadır.

Trakya bölgesinde genel olarak işletme yapıları parçalı ve işletmeler küçük ölçeklidir. İşletme 
yapısına uygun traktör ve tarım makinaları seçiminde yapılan hatalar, ekonomik kullanım süresini doldurmuş traktör ile tarım alet ve makinaları varlığı, ortak makine kullanımının azlığ bölgesinde tarımsal mekanizasyon düzeyinin gelişmesini olumsuz yönde etkilemektedir.

Trakya bölgesinin mekanizasyon düzeyinin istenilen düzeyde olması için işletme büyüklüğü ve üretim desenine uygun traktör ile alet ve makinaların planlanması gerekmektedir. Sahip olunan traktör ile alet ve makinaların uyumu ve bunların birlikte etkin kullanımı da önemlidir. Bu nedenle traktör ile tarım alet ve makinaların kullanımına yönelik eğitim ve bilgilendirme çalışmalar yapılmalı, böylece yeterli işletme büyüklügüne sahip olmayan işletmelerde ortak kullanım yaygınlaştırılmalıdır.

\section{KAYNAKLAR}

Akar M, Çelik A 2017. Muş Ovası Tarım İşletmelerinin Tarımsal Mekanizasyon Özellikleri. Türk Tarım ve Doğa Bilimleri Dergisi, 4(4):491-498.

Akar M, Malaslı MZ, Çelik A 2012. Hatay İlinin Tarımsal Mekanizasyon Özellikleri. 27. Tarımsal Mekanizasyon Ulusal Kongresi, 5-7 Eylül, Samsun.

Altıkat S, Çelik A 2009. Erzurum İlinin Mekanizasyon Özellikleri. Atatürk Üniversitesi Ziraat Fakültesi Dergisi, 40 (2): 57-70.

Altıkat S, Çelik A 2011. Iğdır İlinin Tarımsal Mekanizasyon Özellikleri. Iğdır Üniversitesi Fen Bilimleri Enstitüsü Dergisi, 1(4): 99-106.

Altıntaş E 2015. Eskişehir İli Tarım İşletmelerinde Traktör Kullanımının Ekonomik Analizi. Ankara Üniversitesi Fen Bil. Ens., Tarım Ekonomisi ABD, Doktora Tezi, $302 \mathrm{~s}$.

Altuntaş E 2016. Türkiye'nin Tarımsal Mekanizasyon Düzeyinin Coğrafik Bölgeler Açısından Değerlendirilmesi. Türk Tarım- Gıda Bilim ve Teknoloji Dergisi, 4 (12): 1157-1164.

Arıöz M 2007. Ağrı İlinde Tarım İşletmelerinin Tarımsal Yapı ve Mekanizasyon Özellikleri, Ankara Üniversitesi Fen Bil. Ens., Tarım Makinaları ABD, Yüksek Lisans Tezi, $88 \mathrm{~s}$.

Aslantürk B, Altuntaş E 2018. Malatya İlinin Tarımsal Mekanizasyon Düzeyi. Gaziosmanpaşa Bilimsel Araştırma Dergisi, 7(2): 15-26.

Baran MF, Gökdoğan O, Durgut MR 2014. Batı Marmara Bölgesi'nin Tarımsal Mekanizasyon Özellikleri. Türk Tarım ve Doğa Bilimleri Dergisi, 1 (4): 561-67.

Bilim C, Korucu T, Semerci T 2014. Gaziantep İlinin Tarımsal Mekanizasyon Özellikleri. KSÜ Doğa Bilimleri Dergisi, 17(2): 14-23.

Biondi P, Monarca D, Panaro A 1998. Simple Forecasting Models for Farm Tractor Demand in Italy, France and the United States. Journal of Agricultural Engineering Research, 71: 25-35.

Bozkurt M 2016. Şanlıurfa İli Harran Ovasında
Tarımsal Yapı, Mekanizasyon Özellikleri, Üretim Teknik ve Teknolojilerinin Belirlenmesi. Kahramanmaraş Sütçü İmam Üniversitesi Fen Bil. Ens., Biyosistem Mühendisliği ABD, Yüksek Lisans Tezi, $39 \mathrm{~s}$.

Conley DM, Lambert DA 1981. Farm Tractor Horsepower Demand in Illinois. North Central Journal of Agricultural Economics, 3(2): 119-124.

Doruk İ 2016. Denizli İlinin Tarımsal Mekanizasyon Düzeyinin İncelenmesi. Türk Tarım ve Doğa Bilimleri Dergisi, 3(4): 324-331.

Durgut MR, Arın S 2005. Trakya Yöresi Bağcılığının Mekanizasyon Düzeyi ve Sorunları. Tekirdağ Ziraat Fakültesi Dergisi, 2(3): 287-297.

Gökdoğan O 2012. Isparta İlindeki Tarımsal İşletmelerin Tarımsal Yapısı ve Mekanizasyon Özellikleri. Adnan Menderes Üniversitesi Ziraat Fakültesi Dergisi, 9(2): $13-17$.

Gökdoğan O 2014. Hakkari İlinin Tarımsal Mekanizasyon Durumu. Türk Tarım ve Doğa Bilimleri Dergisi, 1(1): 98-101.

Işık E, Güler T, Ayhan A 2003. Bursa İline İlişkin Mekanizasyon Düzeyinin Belirlenmesine Yönelik Bir Çalışma. Uludağ Üniversitesi Ziraat Fakültesi Dergisi, 17(2): 125-136.

Kayhan IE, Aydın B, Baran MF 2017. Kırklareli İli Tarım İşletmelerinin Tarımsal Yapısı ve Mekanizasyon Düzeyi. Türk Tarım ve Doğa Bilimleri Dergisi, 4(3): 263-270.

Koçak M 2006. Bitlis İlinin Tarımsal Mekanizasyon Durumu, Sorunları ve Çözüm Önerileri. Ankara Üniversitesi Fen Bil. Ens., Tarım Makinaları ABD, Yüksek Lisans Tezi, $84 \mathrm{~s}$.

Koçtürk D, Onurbaş Avcioğlu A 2007. Türkiye'de Bölgelere ve İllere Göre Tarımsal Mekanizasyon Düzeyinin Belirlenmesi. Tarım Makinaları Bilimi Dergisi, 3(1): 17-24.

Korucu T, Aybek A, Sivrikaya F 2015. Türkiye'nin Tarım Bölgeleri Bazında Mekanizasyon Düzeyinin Yersel Değişim Haritalarının Oluşturulması ve Değerlendirilmesi. KSÜ Doğa Bilimleri Dergisi, 18(4): 77-90.

Korucu T, Aybek A, Sivrikaya F, Gürlek E, Mert C, Kozak B 2015. Kahramanmaraş İlinin Tarımsal Mekanizasyon Düzeyinin Haritalanması ve Değerlendirilmesi, KSÜ Doğa Bilimleri Dergisi, 18(2): 10-24.

Kök M 1993. Tunceli İlinin Tarımsal Mekanizasyon Özellikleri ve $\mathrm{Bu}$ Özelliklerin Bölgenin Tarım Potansiyeli Açısından İrdelenmesi Üzerine Bir Araştırma. Çukurova Üniversitesi Fen Bil. Ens., Tarım Makinaları ABD, Yüksek Lisans Tezi, $58 \mathrm{~s}$.

Lüle F, Koyuncu T, Engin KE 2012. Adryaman İlinin Tarımsal Mekanizasyon Düzeyi. 27. Tarımsal Mekanizasyon Ulusal Kongresi, 5-7 Eylül, Samsun.

Oğuz C, Bayramoğlu Z, Ağızan S, Ağızan K 2017. Tarım İşletmelerinde Tarımsal Mekanizasyon Kullanım Düzeyi, Konya İli Örneği. Selçuk Tarım 
ve Grda Bilimleri Dergisi, 31(1): 63-72.

Özgüven M, Türker U, Beyaz A 2010. Türkiye'nin Tarımsal Yapısı ve Mekanizasyon Durumu. GOÜ Ziraat Fakültesi Dergisi, 7(2): 89-100.

Özmen TB 2014. Erzurum, Erzincan ve Bayburt İllerinin (Tra 1 Düzey 2 Bölgesi) Tarımsal Mekanizasyon Özelliklerinin Değerlendirilmesi. Atatürk Üniversitesi Fen Bil. Ens., Tarım Makinaları ABD, Yüksek Lisans Tezi, $66 \mathrm{~s}$.

Özpınar S 2001. Marmara Bölgesi'nin Tarımsal Mekanizasyon Özelliklerinin Belirlenmesi. Tarımsal Mekanizasyon 20. Ulusal Kongresi, 13-15 Eylül, Şanlıurfa.

Sabanc1 A, Sümer SK, Say MS, Has M 2003. Türkiye'de Ekonomik Traktör Parkı ve Gelişimi.

Tarımsal Mekanizasyon 21. Ulusal Kongresi, 3-5 Eylül, Konya.

TÜİK, Türkiye İstatistik Kurumu. Tarımsal Alet ve
Makina İstatistikleri. https://biruni.tuik.gov.tr/ medas/?kn=134\&locale=tr (Erişim Tarihi: 03.12.2018).

Unakitan G, Akdemir B 2007. Tractor Demand Projection in Turkey. Biosystems Engineering, 97: $19-25$.

Unakitan G, Akdemir B 2015. Prediction of Combine's Number by Using ARMAX Model in Turkey. Balkan and Near Eastern Journal of Social Sciences, 1(1): $1-6$.

Witt SF, Witt CA 1992. Modeling and Forecasting Demand in Tourism. Academic Press, London, 208 s.

Yavuz H 2016. Hayvancılık Destekleme Politikalarının Tarımsal İşletmeler Açısından Değerlendirilmesi: Amasya İli Örneği. Gaziosmanpaşa Üniversitesi Fen Bil. Ens., Tarım Ekonomisi ABD, Yüksek Lisans Tezi, $110 \mathrm{~s}$. 